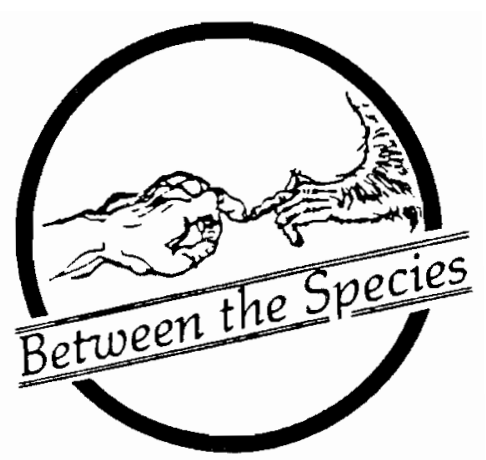

\title{
RETROSPECTIVE (1988-1945)
}

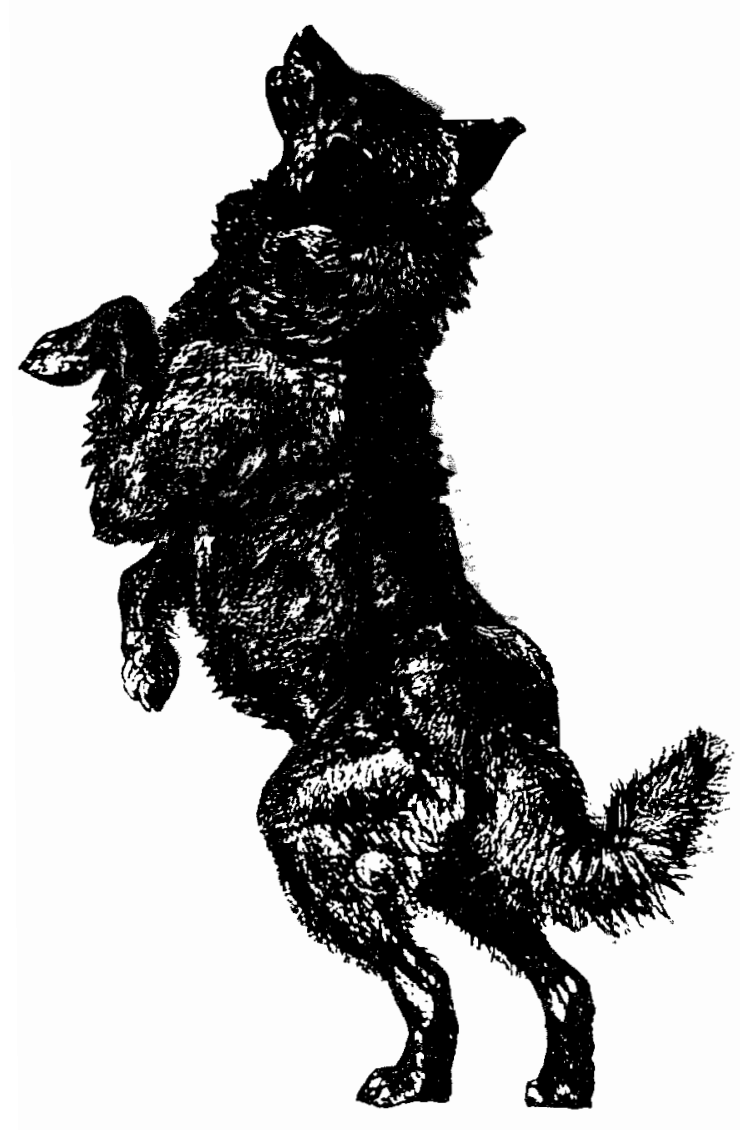

Jim Harter, Animals: 1419 Copyright-Free Illustrations. New York: Dover, 1979

\section{Stephen R. L. Clark University of Liverpool}

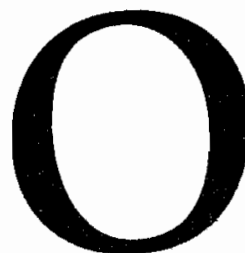

ne of the lessons especially of late antique philosophy is to look upon the bodily person one, in some sense, "is," as one thing, one animal among many others. Really to understand that thing, that animal, the watchful intellect needs to understand a world. This thing here, this human animal, is what it is in part because of things that happened, or did not happen, long before its life began, or it woke to be aware of it. So illuminating retrospectives must incorporate the story of a culture, nation, family. That is obvious to everyone when we deal with clearly

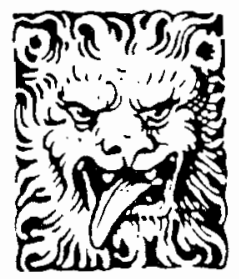

AUTOBIOGRAPHY 
alien cases. Learning and historical imagination must be brought to bear on memoirs of Hellenistic Greek, or Mediaeval Florentine: to make their lives lucid, such as "we" could imagine living, we must go further than their lives. Contemporary English-speakers, if parochial enough, may easily and lazily suppose that any English-speaker is enough like others for a common background to be presupposed, and so neglect imagination and research. But contemporary, English-speaking culture is not homogenous; even British culture is not, let alone the "Western World," and weird misunderstandings of our differences abound: witness a recent American visitor who fondly supposed that all British academic couples have wonderful English nannies! All merely partial histories mislead, but who could write that history of the world, that universe after one peculiar mode, that is the world for this one animal? A true retrospective should begin: And There Was Light.

Beginning - in deference to editorial whim - a little downstream from that singular event: my family rises on the borders of North Wales and England, as an eddy within the confluence of races and traditions that we label "Britain." My mother was the youngest daughter - by some eighteen years - of an" early Labour Member of Parliament. His name (Samuel Finney), and provenance, suggest that there were Irish navvies in the background, brought in to build the railways, though family legend also speaks of gentry come down in the world. He was himself the last survivor of twenty-two children, had worked down in the mines, and chose in the end to be a union-leader rather than M.P. He was a fervent Methodist, taught himself Hebrew and Greek, kept abreast of modern developments in science and scholarship, and died ten years before I was born. One of my earliest memories is of his widow, my grandmother, driving away from home to die in hospital. She had played a large part in my early life: "Finnies," the saying was, "be like cats: they waken up at night" - and demand company. My own children seem to be the same. My father had been an apprentice railway man, won a scholarship to Manchester University, and was thereby set upon a career teaching engineering and running technical colleges. Mother and Father loved at first sight, romantically spotting each other in the country lane near Miss Finney's first (and last) teaching job. I was their youngest son by some ten years. The generations of my extended family are therefore as out of line as are their class-affiliations: I have first cousins well towards or even in retirement, and including grocers, lawyers, poets, town-clerks and a scientific knight. In my near family there are two brothers and their wives, four nephews and a niece; in my immediate, a wife, a son, two daughters and four cats.

British society is at once more mobile and more conscious of class and regional affiliation than some other segments of the Western world at least pretend to be. Our family loyalties were with Labour, and I was raised on memories of the great betrayal, the miners left to fight alone in 1926. As a pupil at an independent school (to which my parents, products of an earlier working-class devotion to learning, had sent me when we moved to Nottingham from Teesside), I was unusual in professing (ill-thought-out) socialist principles, but way back in the nineteen fifties and sixties it was fashionable to be anti-militarist and liberal-minded. My generation, deploring Suez, Hungary and the Cuban Missile crisis all alike, opted out of the Combined Cadet Corps in unprecedented numbers; my son's opts in. I was, or so I now see, an elderly and 
unadventurous child who gradually chose the path of literary skill, scholarship and argumentative technique as a way of surviving boyish hostility. Physically I was not so much cowardly as uncomprehending, not so much clumsy as inattentive. Perhaps I identified a little with our dog: a mongrel runt who apparently believed herself to be a cat! By the time I left to go up to Balliol I had a few close thinking-companions, but none of my close friends now date from those school days. Having no sisters, and attending a single-sex school, I knew women only through my mother and my memories of earlier companions. A radical conversion back to Christianity just before going up confirmed in me the sort of dream that Jewish boys are said to have (or Jewish mothers on their sons' behalf!) that there was something that I had to do, something for which I should be ready, something incompatible with sixties sensualism. It was my second year at university before I quite abandoned that self-dedication and found that girls were more agreeable companions than dreams. The Jewish reference, by the way, was not irrelevant: my grandfather had been attracted - though not, I think, finally deceived - by the creed of British Israel, the historical fantasy that the British were the heirs of the ten "lost tribes." The fantasy touched deep roots: the non-conformist lower classes earlier this century had a strong conviction that they were or had been "slaves in Egypt," that their salvation would be through their loyalty to the covenant.

I have never worked harder than in those first two years at college: from being a recognized, and slowly tolerated, swot and intellectual I was transformed into a bright undergraduate in a university packed tight with them, and with products of a richer class than mine. Who could compete with students whose families had been producing scholars and gentlemen for generations, and who had themselves been writing Latin verse (a useless but engaging pastime that does teach many vital rules of life) since their preparatory school? But Oxford University is a machine for remoulding youth into the image of such scholarship and sometime gentility. By the time I graduated I could even - more or less - cope with dining in All Souls, where I was elected Fellow in 1968. Even so, I deliberately rose late for the first year, so as not to have to share breakfast with the elite.

I had graduated with a Double First in Litterae Humaniores, and thought at first to concentrate on classical scholarship, perhaps to write a thesis on Plato's debt to Pindar (negligible), or on Blake's Metaphysics (a project from which my tutor, Arthur Prior, properly dissuaded me). In the event I wrote a maverick thesis on Aristotle, grounding his ethics and political philosophy in his biological observations and theory. The shape it took owed something to my position outside usual post-graduate life (as a consequence of which I had no contact with the group of postgraduates, including Rosalind and Stanley Godlovitch, who were then introducing Animal Liberation to the philosophical scene), and something to a year spent in Chicago, where I taught undergraduates, hid in a room in the Regenstein Library and occasionally cleaned out the cockroaches from the kitchen of the apartment I shared with three graduate students. What I saw in Aristotle was the sense of humankind as one animal species among many, with distinctive powers that gave us, or some of us, the chance to mirror the world's being, to live from God as centre rather than our sorry selves. The thesis, published as Aristotle's Man in 1975, had all the usual faults of unclarity and crammed 
quotation, but identified — for those who understood it - how I thought it right to reason about what to do and think.

I had gone to Chicago partly to get out of Oxford, partly to while away the time until the (Jewish!) girl I thought to marry should come back from a teaching job in Persia. A visit there had gone disastrously wrong; other - and highly unsuitable - relationships led nowhere (one Okinawan girl was hurriedly summoned home when her mother learnt of my existence). Soon after my return I married a scholar and research fellow of Somerville instead, herself a product of Liverpool Scot, Somerset and Southern Welsh: our wedding celebration was very nearly the last time that either of us ate dead animals with any pleasure. Our children now can hardly comprehend the fact that once we did. Our joint conversion came when we were staying at my parents' home in Suffolk: they had retired to country life when I went up to Oxford. The farm next door took calves in to be reared for beef: the noise of their complaints kept us awake at night, and we at last decided that we could no longer finance practices like that.

In 1974 we moved to Glasgow University, where the lectures I had planned on issues related to the treatment of non-human animals took shape. Those lectures became The Moral Status of Animals, published in 1977 (and in slightly revised paperback in 1982). I was astonished, and hurt, by the offence they caused: not hurt by any offence caused to the uncaring and unthinking, of course, but by the reactions of those who might have been thought allies. Apparently people could not see when I was joking, or when I was advancing a thesis only to change or controvert it by a necessary antithesis. Apparently my whole strategy was something that they could not recognize: the "right" way of doing philosophy, I was patronizingly informed, was to lay out demonstrative arguments from necessarily acknowledged principles to incontrovertible judgements. I had sinned against the light by offering no single system within which to work, by suggesting that utilitarian principle could not, by itself, give any substantive result, that "rights theorists" could not finally or usefully close all exits, that there was more to moral conversion than to follow any single argument right to its end. I had been trained, after all, as a classical scholar and had already laid out the general form of my post-Aristotelian philosophy for those who cared. What I aimed to produce was the possibility of a gestalt switch, a transformation of world-view, a genuinely realistic vision of the way things are for God, for the one and abiding pattern to which all things move. That animals were "morally considerable" was a necessary consequence of that vision of the world's beauty, a vision since described more lovingly by Erazim Kohak.

Merely scholastic argument about "rights," I thought, got nowhere unless someone explained what was the point of having rights. Since then I have come to realize how tightly rights are tied to a particular "liberal" politics which are not mine. My early, and familial, socialism has gradually been transformed into a vision of "shalom," a traditional and even conservative understanding of human and other duty. I am by now a kind of anarcho-conservative - which is a commoner position than some schoolmen realize. Utilitarian discussion I thought even less sensible, a pretense of moral objectivity that never could in fact produce a single definite moral conclusion. Peter Singer and Raymond Frey agreed on almost every theoretical issue: why did they disagree in practice? Could 
either give a genuinely informed calculation of the effect of action either way? Could even Tom Regan's wish to give all "subjects-of-alife" the very rights that American liberals have wished for human beings - a theory with which I had a lot more sympathy than he with mine - avoid scholasticism? Were not all these worthy and high-principled people simply concealing even from themselves what vision it was they served? Were any of us really quite so sure how a redeemed humanity might behave, in this real world? Granted that the "old" (or not so old) way of looking at the world, and animals, amounted to a refusal to face facts - a refusal of much the same kind that Iris Murdoch has identified as sin in personal relationships - what were the facts, how should we live at peace with what there was?

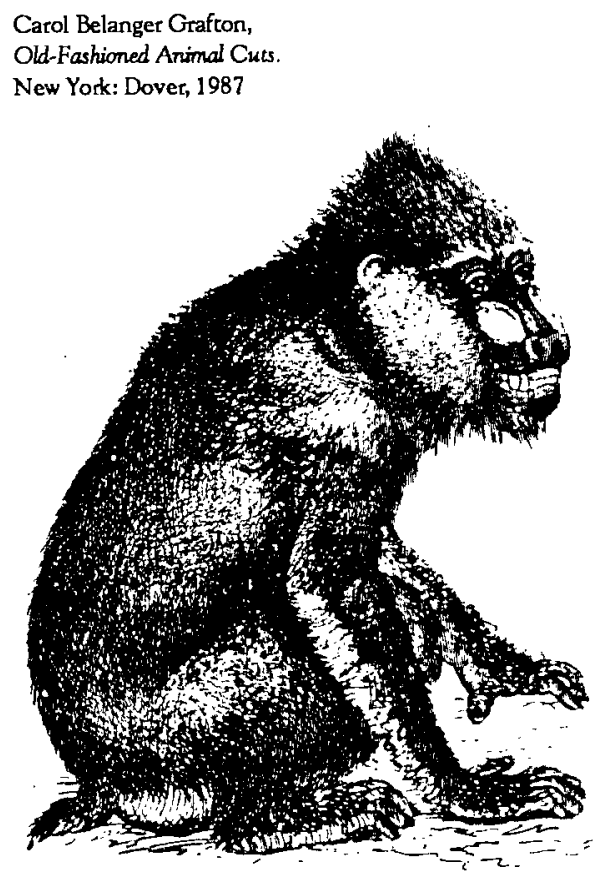

$\longrightarrow$ o seek to solve those problems, and prompted by a friendly publisher, I wrote The Nature of the Beast (1980; pbk. 1983), a deliberately simple study of what was involved in understanding animals — including, obviously, ourselves. Some critics assumed that it was yet another plea for "animal rights," instead of an account of what animals were, and how we might get onto friendly terms with them. It was also yet another attempt to show people what a moral argument should actually be like. No moral advice is ever convincing if it is offered merely as the conclusion of even a valid argument from previously accepted principles. The audience can always say (and will) that other principles defeat the inference, that after all they will abandon those accepted principles, that even if the argument seems valid it must be less authoritative than "what we already know." No sceptical argument, after all (or so we're often told), has greater weight than the sheer there-ness of consensus reality. The same must be true of any single moral argument. To change a moral vision all the world must be transformed: everything must support the new way, not just a cosy syllogism earnestly debated by ignorant schoolmen. Argument of the kind preferred by some philosophers is useless: there is nothing we can say strictly to refute a lunatic convinced that the world is against him, that he is the only really human consciousness, that animals are insentient or that there are no moral wrongs. Nothing, that is, that he will admit to be both true and destructively inconsistent with the theses he believes. As Chesterton (another author who had enormous influence on me) remarked, the lunatic is not cured when he is 
"shown" to be inconsistent, but when a larger and brighter world breaks in on him.

What was at stake for me was more than the fate of animals at our hands - though that was and remains a matter of my deep concern. What I had hated in "modern philosophy" was the conceit that "we philosophers" could sensibly debate and settle issues that had engrossed our moral and intellectual betters, without stepping outside the narrow confines of fashionable, academic philosophy, and without ever acknowledging any duty to reform, re-form our lives. Philosophy, said Descartes sardonically, "affords the means of discoursing with an appearance of truth on all matters and commands the admiration of the more simple." A resurrected Descartes might discover that such conceit had bred a violent contempt for such "philosophists" among the more politically and socially active. Why on earth should honest and dedicated people put up with being told they were, and always had been, talking nonsense by the sort of deliberately unimaginative and ill-informed schoolmen who had claimed the garments of the Lady Philosophy? How can we claim to be true philosophers if we have no love of truth, nor any readiness to change our opinions and our ways?

These questions absorbed me when I came to write Gifford lectures for Glasgow: what was the point of doing philosophy if it did not leave us better able to endure or to enjoy the world? The question was Epictetus's: in the past I had so disliked the attitude that Stoics (and Thomists) took to non-human animals that I had neglected the real virtues of that tradition - which was, after all, the very tradition of moral and philosophical discourse in which I grounded myself. In From Athens to Jerusalem (1984), and now also in Limits and Renewals (a three volume work growing out of the Stanton Lectures I am currently giving in Cambridge University), I seek to draw attention to the ancient way, the perennial philosophy that always had the resources for a better and more truthful way with animals and with the biosphere.

Our ten-year stay in Glasgow earned us many friends in the academy and in the church: for three years I was in training for the non-stipendiary priesthood of the Scottish Episcopal Church. A change of rector in the local church, much more than a change of bishop, made the dream impossible to realize, but one event from that time was a crucial one. Attending a conference on charismatics as part of my training, I was "baptised in the Spirit." The experience itself - which did not occur amid scenes of mass enthusiasm, but alone in a quiet room with the baptising bishop - was an extraordinary one: a sense of being carried out of my depth, whirled round and remade. I returned home "drunk with the Spirit," in an exasperatingly good temper and deeply aware of the inner reality of those I met. That drunkenness passed in me, but from that time on (it was just before I gave the Giffords) I have seen more truth in old-fashioned religion than good liberal intellectuals usually allow. Perhaps I thereby acknowledged my community with that non-conformist ancestry.

It would be easy (and simple-minded) to see providence at work in our next move, to Liverpool. "We are doing," we jokingly remarked, "a tour of decaying west-coast ports!" My second brother and his family already lived here; my parents had left Suffolk to join them here after my father's heart attack - an attack whose ill-effects were exacerbated by faulty drug treatment. Liverpool was also the home of one of the six British veterinary schools, and one that 
seemed especially open to movement and radical enquiry. The Centre for the Study of Animal Affairs, recently established here with myself as director, is a network of psychologists, zoologists, philosophers and veterinary scientists who share the conviction that questions about the understanding and the treatment of non-human animals are open to rational enquiry.

Our move to Liverpool also, unexpectedly, added a third child to our family: "new house, new child," my mother had murmured irritatingly. Suddenly we were thrown back a decade, to broken nights and children's stories, just as we thought that our two older children were moving out into senior school life - attending the same kind of (independent) schools that both of us had done. Somehow we both keep teaching and researching; the Department of Philosophy at Liverpool is one of those to profic by the present troubles, by importing philosophers from elsewhere, and looks set to be established as a north-western centre of the craft; somehow our children are clothed, fed and entertained.

The post-Aristotelian, neo-Platonic synthesis that I have been advocating now for nearly twenty years gets a better hearing nowadays. If Tom Regan is irritated (justly enough) by those who attribute the defence of "animal rights" to Peter Singer, I too am irritated by claims that Tom is the "acknowledged leader" of those who seek a better way for animals. It is "the argument," the Logos, that is our leader - not one simple syllogism or scholastic thesis, but the whole way of seeking to see things truly, without self-deception or greed "that is the ancient precondition of our being "in touch." Treating animals right, and treating arguments aright, cannot in the end be separated from the perennial task of living as God's friends and servants in the world He makes. That task is one we can accomplish only - if at all - by being ready to accept God's presence with us now: to accept God's presence, to be alive to it, is also to be alive to the reality of all the creatures with whom we share the world, and to seek His peace.

With which high-minded proclamation, and sardonically aware how feebly, inconsistently and narrowly this creature here acts out the vision, I conclude my mid-term retrospective.

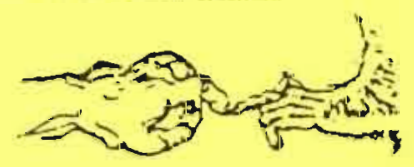

\section{BOOKS RECEIVED}

Virginia McKenna, Will Travers and Jonathan Wray, eds. Beyond the Bars: The Zoo Dilemma

Rochester, Vermont: Thorsons Publishing Group, 1987 204p, index
$\$ 12.95$ paper

Marjorie Spiegel

The Dreaded Comparison: Human

and Animal Slavery

Philadelphia: New Society

Publishers, 1988

$98 \mathrm{p}$, notes

$\$ 27.95$ hardback/ $\$ 7.95$ paper 